\title{
Design and development of ICCA as a dual inhibitor of GPIlb/llla and P-selectin receptors
}

This article was published in the following Dove Press journal:

Drug Design, Development and Therapy

\author{
Haiyan Chen' \\ An Lu' \\ Xiaoyi Zhang' \\ Lin Gui' \\ Yaonan Wang' \\ Jianhui $\mathrm{Wu}^{\prime}$ \\ Hua Feng' \\ Shiqi Peng' \\ Ming Zhao ${ }^{1,2}$ \\ 'Beijing Area Major Laboratory \\ of Peptide and Small Molecular \\ Drugs, Engineering Research Center \\ of Endogenous Prophylactic of \\ Ministry of Education of China, \\ Beijing Laboratory of Biomedical \\ Materials, College of Pharmaceutical \\ Sciences, Capital Medical University, \\ Beijing, People's Republic of China; \\ ${ }^{2}$ Department of Biomedical Science \\ and Environmental Biology, Kaohsiung \\ Medical University, Kaohsiung, Taiwan
}

Correspondence: Shiqi Peng; Ming Zhao Beijing Area Major Laboratory of Peptide and Small Molecular Drugs, Engineering Research Center of Endogenous Prophylactic of Ministry of Education of China, Beijing Laboratory of Biomedical Materials, College of Pharmaceutical Sciences, Capital Medical University, No 10 Xitoutiao, You An Men, Beijing 100069, People's Republic of China Tel +86 I0 839| $|528 ;+86 \quad 10839| \quad 1535$ Fax $+86108391 \quad 1533 ;+86108391 \quad 1533$ Email sqpeng@bjmu.edu.cn; mingzhao@bjmu.edu.cn
Background: The impact of upregulation of platelet membrane glycoprotein (GP)IIb/IIIa and P-selectin on the onset of arterial thrombosis, venous thrombosis, and cancer encourages to hypothesize that dual inhibitor of GPIIb/IIIa and P-selectin receptors should simultaneously inhibit arterial thrombosis, block venous thrombosis, and slow tumor growth.

Methods: For this reason, the structural characteristics and the CDOCKER interaction energies of 12 carbolines were analyzed. This led to the design of 1-(4-isopropyl-phenyl)- $\beta$-carboline-3carboxylic acid (ICCA) as a promising inhibitor of GPIIb/IIIa and P-selectin receptors.

Results: The synthetic route provided ICCA in 48\% total yield and $99.6 \%$ high-performance liquid chromatography purity. In vivo $5 \mu \mathrm{mol} / \mathrm{kg}$ oral ICCA downregulated GPIIb/IIIa and P-selectin expression thereby inhibited arterial thrombosis, blocked venous thrombosis, and slowed down tumor growth, but did not damage the kidney and the liver.

Conclusion: Therefore, ICCA could be a promising candidate capable of downregulating GPIIb/IIIa and P-selectin receptors, inhibiting arterial thrombosis, blocking venous thrombosis, and slowing down tumor growth.

Keywords: thrombosis, cancer, GPIIb/IIIa, P-selectin

\section{Introduction}

Deep venous embolism, arterial embolism, cerebral vascular embolism, and tumor are responsible for elevated mortality worldwide. ${ }^{1-5}$ Discovery of lead compounds capable of simultaneously inhibiting arterial thrombosis, preventing venous thrombosis, and slowing down tumor growth is of clinical importance. This pushes the inhibitors of P-selectin and glycoprotein (GP)IIb/IIIa receptors into our view.

$\mathrm{P}$-selectin in the $\alpha$-granules of the resting platelets is expressed on the surface of the activated platelet and thereby is converted to a soluble form. Findings indicate that the soluble P-selectin plays an important role in thrombosis and tumor growth; eg, the increase of serum P-selectin reflects the risk of thrombotic disease attack, while relevant rise of P-selectin mirrors the enhancement of tumor growth. ${ }^{6-10}$ Several lines of evidence suggest that P-selectin antagonist can inhibit the attack of the thrombotic disease and slow down tumor growth. ${ }^{11-14}$ As the most abundant complex on the surface of platelets, GPIIb-IIIa is $\mathrm{Ca}^{2+}$-dependent receptor and is one member of integrin family. On the surface of activated platelets, but not on the resting platelets, GPIIb/IIIa effectively binds plasma fibrinogen (FIB) and initiates platelet aggregation. Similarly, an antagonist of GPIIb/IIIa can inhibit the attack of thrombotic disease and slow down tumor growth. ${ }^{15-18}$ These findings imply that dual inhibitor of P-selectin and GPIIb/IIIa receptors should simultaneously inhibit arterial thrombosis, venous thrombosis, and tumor growth. In this context, the structural characteristics of the previously reported carbolines were 
analyzed. These carbolines inhibited arterial thrombosis; ${ }^{19}$ targeted GPIIb/IIIa receptor thereby inhibited arterial thrombosis, ${ }^{20}$ targeted $\mathrm{P}$-selectin receptor thereby inhibited arterial thrombosis and venous thrombosis, ${ }^{21}$ slowed down tumor growth, ${ }^{22,25,26}$ or simultaneously inhibited thrombosis and slowed down tumor growth; ${ }^{22,23}$ or targeted P-selectin receptor thereby simultaneously inhibited arterial thrombosis and slowed down tumor growth. ${ }^{24}$ The findings led to 10 known carbolines been docked into the active pockets of P-selectin and GPIIb/IIIa receptors. The CDOCKER interaction energy led to the design and the development of 1-(4-isopropylphenyl)- $\beta$-carboline-3-carboxylic acid (ICCA) as a candidate capable of simultaneously downregulating P-selectin and GPIIb/IIIa receptors.

\section{Materials and methods General}

The reactions were performed under nitrogen (1 bar). On Bruker Avance II-300 spectrometers, ${ }^{1} \mathrm{H}(300 \mathrm{MHz})$ and ${ }^{13} \mathrm{C}(75 \mathrm{MHz})$ nuclear magnetic resonance (NMR) spectra were measured by using dimethyl sulfoxide (DMSO- $d_{6}$ ) as the solvent and tetramethylsilane as the internal standard. A PerkinElmer ${ }^{\circledR} 983$ instrument was used to record infrared spectra. A 9.4-T SolariX Fourier transform (FT) ion cyclotron resonance mass spectrometer (Bruker Corp., Billerica, MA, USA) was used to record electrospray ionization (ESI) (+/-)-ion cyclotron resonance-FT-mass spectrometry (MS) spectra. On a XT5 hot stage microscope (Beijing Keyi Electro-optic Instrument Factory, China), melting points were tested. Chromatography was done with sephadex- $\mathrm{LH}_{20}$ or silica gel $\mathrm{GF}_{254}$ or silica gel $\mathrm{H}_{60}$ (Qingdao Marine Chemical Plant, China). Before use, all solvents were distilled and dried by following literature procedures. High-performance liquid chromatography (HPLC) purities $\left(\mathrm{C}_{18}\right.$ column, $4.6 \times 150 \mathrm{~mm}$; Waters Corporation, Milford, MA, USA) of all compounds were 95.34\%-99.63\%. Alliance separation module e2695 HPLC system (Waters Corporation) was used to separate the compounds by using a Waters XTerra C18 reversed-phase column $(2.1 \times 150 \mathrm{~mm}, 5 \mu \mathrm{m}$; Waters Limited, Hertfordshire, UK). This column was protected by a guard column of the same material $(5 \times 10 \mathrm{~mm}, 5 \mu \mathrm{m})$, while the column thermostat was maintained at $40^{\circ} \mathrm{C}$. The solution of compound in $5 \mu \mathrm{L}$ of ultrapure water was loaded onto the column for analysis. The mobile phase consisted of $30 \%$ water and $70 \%$ methyl alcohol. The flow rate was $0.3 \mathrm{~mL} / \mathrm{min}$. The column was washed with a mixed solvent of 5\% water and $95 \%$ methanol and was equilibrated in the initial condition for 30 minutes. Ultraviolet (UV) absorption spectrum was recorded online. The UV detector was set to a scanning range of 200-400 nm, and the chromatograms of compounds were monitored at a wavelength of $280 \mathrm{~nm}$.

Human myeloid leukemia cells (K562), human nonsmall cell lung cancer cells (A549), and nonsmall cell lung cancer cells (95D) were purchased from American Type Culture Collection (Manassas, VA, USA). Mice ascites tumor cells (S180) were purchased from the Animal Center of Peking University (Beijing, People's Republic of China).

From the Laboratory Animal Center of Capital Medical University, male Institute of Cancer Research (ICR) mice (20-22 g) and Sprague Dawley rats (220-250 g) were purchased. Ethics Committee of Capital Medical University reviewed and approved the protocols of all evaluations. This means that the animal welfare fulfilled the requirements of Animal Welfare Act and National Institute of Health Guide for Care and Use of Laboratory Animals. All biological data were statistically analyzed with analysis of variance. Least significant difference was used for multiple group comparison. SPSS Version 19.0 (IBM Corporation, Armonk, NY, USA) was used to perform the analysis, and a $P$-value $<0.05$ was considered statistically significant.

\section{Synthesis}

Preparation of (IR, 3S)- I-(4-isopropyl-phenyl)2,3,4,9-tetrahydro- $\beta$-carboline-3-carboxylic acid benzyl esters (I)

At room temperature, a solution of $4.47 \mathrm{~g}(15.2 \mathrm{mmol})$ of $L$-Trp-OBzl, $3.0 \mathrm{~mL}(18.2 \mathrm{mmol})$ of cuminic aldehyde, $50 \mathrm{~mL}$ of $\mathrm{CH}_{2} \mathrm{Cl}_{2}$, and $5 \mathrm{~mL}$ of trifluoroacetic acid was stirred for 24 hours, adjusted to $\mathrm{pH}$ of 8 by using aqueous $\mathrm{NaHCO}_{3}$ (5\%), and successively washed with aqueous $\mathrm{NaHCO}_{3}(5 \%)$ and saturated aqueous $\mathrm{NaCl}$. The separated $\mathrm{CH}_{2} \mathrm{Cl}_{2}$ phase was dried over anhydrous $\mathrm{Na}_{2} \mathrm{SO}_{4}$, filtered, and evaporated under vacuum. The residue was separated on silica gel column (petroleum ether/acetone, 5:1) to give $3.85 \mathrm{~g} \mathrm{(60 \% )}$ of (1) as colorless powders. ${ }^{1} \mathrm{H}$ NMR (300 MHz, DMSO- $\left.d_{6}\right)$ : $\delta / \mathrm{ppm}=10.60(\mathrm{~s}, 1 \mathrm{H}), 7.54(\mathrm{~d}, \mathrm{~J}=7.5 \mathrm{~Hz}, 1 \mathrm{H}), 7.22(\mathrm{~m}, 12 \mathrm{H})$, $5.31(\mathrm{~s}, 1 \mathrm{H}), 5.13(\mathrm{~s}, 2 \mathrm{H}), 3.88(\mathrm{~m}, 1 \mathrm{H}), 3.10\left(\mathrm{dd}, \mathrm{J}_{1}=4.8\right.$ $\left.\mathrm{Hz}, \mathrm{J}_{2}=15.3 \mathrm{~Hz}, 1 \mathrm{H}\right), 2.97\left(\mathrm{dd}, \mathrm{J}_{1}=6.9 \mathrm{~Hz}, \mathrm{~J}_{2}=14.7 \mathrm{~Hz}, 1 \mathrm{H}\right)$, $2.89(\mathrm{~s}, 1 \mathrm{H}), 2.86(\mathrm{~m}, 1 \mathrm{H}), 1.18(\mathrm{~d}, \mathrm{~J}=6.6 \mathrm{~Hz}, 6 \mathrm{H})$; ESI-MS $(\mathrm{m} / \mathrm{e}): 425[\mathrm{M}+\mathrm{H}]^{+}$.

Preparation of benzyl I-(4-isopropylphenyl)- $\beta$ carboline-3-carboxylate (2)

A mixture of $6.0 \mathrm{~g}(14.15 \mathrm{mmol})$ of (1), $50 \mathrm{~mL}$ of 1,4-dioxane, and $2.37 \mathrm{~g}(21.3 \mathrm{mmol})$ of $\mathrm{SeO}_{2}$ was stirred at $70^{\circ} \mathrm{C}$ for 
6 hours. The formed precipitates were removed from the reaction mixture by filtration, the filtrate was evaporated under vacuum, and the residue was purified on silica gel column (petroleum ether/acetone, 8:1) to give $5.3 \mathrm{~g}(89 \%)$ of (2) as colorless powders. ${ }^{1} \mathrm{H}$ NMR (300 MHz, DMSO- $\left.d_{6}\right)$ : $\delta / \mathrm{ppm}=11.93(\mathrm{~s}, 1 \mathrm{H}), 8.94(\mathrm{~s}, 1 \mathrm{H}), 8.43(\mathrm{~d}, \mathrm{~J}=6.0 \mathrm{~Hz}, 1 \mathrm{H})$, 7.94 (d, J=9.0 Hz, 2H), 7.70 (d, J=9.0 Hz, 1H), 7.53 (m, $5 \mathrm{H}), 7.36(\mathrm{~m}, 4 \mathrm{H}), 5.46(\mathrm{~s}, 2 \mathrm{H}), 3.03(\mathrm{~m}, 1 \mathrm{H}), 1.30(\mathrm{~d}, \mathrm{~J}=6.0$ $\mathrm{Hz}, 1 \mathrm{H}) ;{ }^{13} \mathrm{C}$ NMR $\left(75 \mathrm{MHz}, \mathrm{DMSO}-d_{6}\right): \delta / \mathrm{ppm}=165.89$, $149.84,142.81,141.95,137.13,137.05,135.68,135.07$, $129.49,129.06,128.97,128.45,127.20,122.46,121.62$, 120.83, 117.06, 113.27, 66.48, 33.85, 24.29; ESI-MS (m/z): $421[\mathrm{M}+\mathrm{H}]^{+}$.

\section{Preparation of ICCA}

A $0^{\circ} \mathrm{C}$ solution of $3.5 \mathrm{~g}(8.30 \mathrm{mmol})$ of (2) in $30 \mathrm{~mL}$ 1,4-dioxane was adjusted to $\mathrm{pH}$ of 12 by $15 \mathrm{~mL}$ aqueous $\mathrm{NaOH}(2 \mathrm{M})$. This reaction mixture was stirred at $0^{\circ} \mathrm{C}$ for 24 hours, and the thin-layer chromatography (petroleum ether/acetone, 4:1) indicated the complete disappearance of (2). This reaction mixture was adjusted to $\mathrm{pH}$ of 2 by $5 \%$ aqueous $\mathrm{KHSO}_{4}$ to form light yellow precipitates. The precipitates were filtered to give $2.48 \mathrm{~g}(90 \%)$ of ICCA as light-yellow powders. Melting point: $268^{\circ} \mathrm{C} \sim 270^{\circ} \mathrm{C}$. IR $\left(\mathrm{KBr}, \mathrm{cm}^{-1}\right)$ : 3,270, 2,961, 2,865, 1,738, 1,622, 1,593, 1,559, 1,498, 1,479, 1,456, 1,383, 1,352, 842; ${ }^{1} \mathrm{H}$ NMR $\left(300 \mathrm{MHz}, \mathrm{DMSO}-d_{6}\right): \delta / \mathrm{ppm}=12.49(\mathrm{~s}, 1 \mathrm{H})$, 11.90 (s, 1H), 8.89 (s, 1H), 8.41 (d, J=7.8 Hz, 1H), 8.00 (d, $\mathrm{J}=8.4 \mathrm{~Hz}, 2 \mathrm{H}), 7.70$ (d, J=8.4 Hz, 1H), $7.60(\mathrm{t}, \mathrm{J}=7.8 \mathrm{~Hz}$, 1H), 7.49 (d, J=8.4 Hz, 2H), 7.33 (t, J=7.2 Hz, 1H), 3.03 (m, 1H), 1.30 (d, J=6.9 Hz, 1H); ${ }^{13} \mathrm{C}$ NMR (75 MHz, DMSO- $d_{6}$ ): $\delta / \mathrm{ppm}=167.26,149.81,142.29,142.01,137.73,135.62$, $134.99,129.80,129.17,129.04,127.14,122.41,121.64$, 120.78, 116.45, 113.24, 33.85, 24.30; ESI-MS (m/z): 329 $[\mathrm{M}-\mathrm{H}]^{-}$; HPLC: $99.63 \%$ (retention time $=11.538$ minutes, $\left.\mathrm{CH}_{3} \mathrm{OH} / \mathrm{H}_{2} \mathrm{O}=70 / 30, \lambda=280 \mathrm{~nm}\right)$.

\section{Antiproliferation in vitro assay}

The in vitro viability assays of human myeloid leukemia cells (K562), ascites tumor cells (S180), human nonsmall cell lung cancer cells (A549), and nonsmall cell lung cancer cells (95D) were performed by using 3-(4,5-dimethylthiazol-2yl)-2,5-diphenyltetrazolium bromide (MTT) procedure of the literature. ${ }^{22}$

\section{Antitumor in vivo assay on $\mathrm{SI} 80$ mice}

The injection of doxorubicin (a known intercalator, $2 \mu \mathrm{mol} /$ $\mathrm{kg}$ /day, positive control) in normal saline for 9 consecutive days, the oral carboxymethyl cellulose sodium (CMCNa; $0.5 \%$, negative control) for 9 consecutive days, and the oral suspension of ICCA ( $5 \mu \mathrm{mol} / \mathrm{kg} /$ day) in CMCNa $(0.5 \%)$ for 9 consecutive days were carried out on S180 mouse model (each 12) by using the procedure of the literature to perform the antitumor in vivo assay. ${ }^{25}$

\section{Measuring serum alanine transaminase (ALT)}

Serum glutamic-pyruvic transaminase (GPT) was measured by using the procedure of the literature and ALT/GPT assay kit (Nanjing Jiancheng Bioengineering Institute, Nanjing, People's Republic of China). ${ }^{30}$ To prepare serum, $0.5 \mathrm{~mL}$ blood was obtained from S180 mice treated with CMCNa, from S180 mice treated with ICCA $(5 \mu \mathrm{mol} / \mathrm{kg})$, or from healthy ICR mice. At $4^{\circ} \mathrm{C}$, the blood was centrifuged $(1,000 \mathrm{~g})$ for 10 minutes to prepare serum. To all wells, $20 \mu \mathrm{L}$ matrix solution was added. To each standard well, $5 \mu \mathrm{L}$ standard solution was added. To each testing well, $5 \mu \mathrm{L}$ serum from healthy ICR mice, from S180 mice treated with $\mathrm{CMCNa}$, or from S180 mice treated with ICCA ( $5 \mu \mathrm{mol} / \mathrm{kg}$ ) was added. The well was incubated at $37^{\circ} \mathrm{C}$ for 30 minutes. To all wells, $20 \mu \mathrm{L}$ of dinitrophenylhydrazine was added. To each control well, $5 \mu \mathrm{L}$ of distilled water was added, and the well was incubated at $37^{\circ} \mathrm{C}$ for 20 minutes. To each well, $200 \mu \mathrm{L}$ of sodium hydroxide solution $(0.4 \mathrm{M})$ was added, and the plate was gently tapped for 15 minutes to ensure thorough mixing. The plate was read at $510 \mathrm{~nm}$ with microtiter plate reader to record OD value. By using the standard curve, serum concentration of ALT was calculated.

\section{Measuring serum aspartate aminotransferase (AST)}

Serum glutamic-oxaloacetic transaminase (GOT) was measured by using the procedure of the literature and AST/GOT assay kit (Nanjing Jiancheng Bioengineering Institute). ${ }^{30}$ To prepare serum, $0.5 \mathrm{~mL}$ blood was obtained from S180 mice treated with $\mathrm{CMCNa}$, from S180 mice treated with ICCA $(5 \mu \mathrm{mol} / \mathrm{kg})$, or from healthy ICR mice. At $4^{\circ} \mathrm{C}$, the blood was centrifuged $(1,000 \mathrm{~g})$ for 10 minutes. To all wells, $20 \mu \mathrm{L}$ matrix solution was added. To each standard well, $5 \mu \mathrm{L}$ standard solution was added. To each testing well, $5 \mu \mathrm{L}$ serum from healthy ICR mice, from S180 mice treated with CMCNa, or from S180 mice treated with ICCA ( $5 \mu \mathrm{mol} / \mathrm{kg})$ was added. The well was incubated at $37^{\circ} \mathrm{C}$ for 30 minutes. To all wells, $20 \mu \mathrm{L}$ of dinitrophenylhydrazine was added. To each control well, $5 \mu \mathrm{L}$ of distilled water was added, and the well was incubated at $37^{\circ} \mathrm{C}$ for 20 minutes. To each well, $200 \mu \mathrm{L}$ of sodium hydroxide solution $(0.4 \mathrm{M})$ was added, and the plate was gently tapped for 15 minutes to ensure 
thorough mixing. The plate was read at $510 \mathrm{~nm}$ with microtiter plate reader to record OD value. By using the standard curve, serum concentration of AST was calculated.

\section{Measuring serum creatinine $(\mathrm{Cr})$}

Serum Cr was measured by following the procedure of the literature and the kit (Nanjing Jiancheng Bioengineering Institute). ${ }^{30}$ To prepare serum, $0.5 \mathrm{~mL}$ blood was obtained from S180 mice treated with CMCNa, or from S180 mice treated with ICCA $(5 \mu \mathrm{mol} / \mathrm{kg})$, or from healthy ICR mice. At $4^{\circ} \mathrm{C}$, the blood was centrifuged $(1,000 \mathrm{~g})$ for 10 minutes. To each standard well, $6 \mu \mathrm{L}$ of the standard solution was added. To each control well, $6 \mu \mathrm{L}$ of distilled water was added. To each testing well, $6 \mu \mathrm{L}$ of serum from healthy ICR mice, from $\mathrm{S} 180$ mice treated with $\mathrm{CMCNa}$, or from $\mathrm{S} 180$ mice treated with ICCA $(5 \mu \mathrm{mol} / \mathrm{kg})$ was added. To the well, $60 \mu \mathrm{L}$ enzyme solution A was added. The well was incubated at $37^{\circ} \mathrm{C}$ for 5 minutes and was read at $546 \mathrm{~nm}$ by using a microtiter plate reader to record OD value $\left(A_{1}\right)$. The well was incubated at $37^{\circ} \mathrm{C}$ for 30 minutes. To the well, $60 \mu \mathrm{L}$ enzyme solution B was added. The well was incubated at $37^{\circ} \mathrm{C}$ for 5 minutes and read at $546 \mathrm{~nm}$ by using a microtiter plate reader to record OD value $\left(\mathrm{A}_{2}\right)$. The contents of $\mathrm{Cr}$ in samples were calculated by following the equation of the kit, which was shown in the Supplementary materials.

\section{Measuring serum blood urea nitrogen (BUN)}

The measurement of BUN was performed by following the procedure of the kit (Shanghai Lianshuo Biological Technology Co. Ltd., Shanghai, People's Republic of China). To prepare serum, $0.5 \mathrm{~mL}$ blood was obtained from $\mathrm{S} 180$ mice treated with CMCNa, from S180 mice treated with ICCA (5 $\mu \mathrm{mol} / \mathrm{kg}$ ), or from healthy ICR mice. At $4^{\circ} \mathrm{C}$, the blood was centrifuged $(3,000 \mathrm{~g})$ for 10 minutes. Then, $50 \mu \mathrm{L}$ standard solution and $50 \mu \mathrm{L}$ streptavidin-horseradish peroxidase (streptavidin-HRP) were added into each standard well, and $10 \mu \mathrm{L}$ anti-BUN antibody and $50 \mu \mathrm{L}$ streptavidin-HRP were successively added to each testing well having $40 \mu \mathrm{L}$ serum from healthy ICR mice, from S180 mice treated with $\mathrm{CMCNa}$, or from S180 mice treated with ICCA $(5 \mu \mathrm{mol} / \mathrm{kg})$. At $37^{\circ} \mathrm{C}$, the well was incubated for 60 minutes and then washed five times. For coloration $50 \mu \mathrm{L}$ chromogen solution A and $50 \mu \mathrm{L}$ chromogen solution B (from the kit) were added to the well, and the well was incubated at $37^{\circ} \mathrm{C}$ in dark for 15 minutes. To stop the reaction, the well received $50 \mu \mathrm{L}$ stop solution (from the kit). The OD value was measured at $450 \mathrm{~nm}$ within 15 minutes of the addition of the stop solution. By using standard curve, serum concentration of BUN was calculated.
Mouse and rat arterial thrombus weight assays

Arterial thrombus weight assay was performed on male ICR mouse (22-25 g, each 12) model or on male Sprague Dawley rat (200-220 g, each 12) model by following the procedure of the literature. ${ }^{19,21}$ In mouse arterial thrombus weight assay, $0.5 \% \mathrm{CMCNa}(10 \mathrm{~mL} / \mathrm{kg}$, negative control), a suspension of aspirin in $0.5 \% \mathrm{CMCNa}(240 \mu \mathrm{mol} / \mathrm{kg}$, positive control), or a suspension of ICCA in $0.5 \% \mathrm{CMCNa}(5 \mu \mathrm{mol} / \mathrm{kg})$ was given orally. In rat arterial thrombus weight assay, $0.5 \%$ $\mathrm{CMCNa}(3 \mathrm{~mL} / \mathrm{kg})$, a suspension of aspirin in $0.5 \% \mathrm{CMCNa}$ $(167 \mu \mathrm{mol} / \mathrm{kg})$, or a suspension of ICCA in $0.5 \% \mathrm{CMCNa}$ $(5 \mu \mathrm{mol} / \mathrm{kg})$ was given orally.

\section{P-selectin and GPIlb/Illa expression assays}

P-selectin expression assay was based on the experiment of an enzyme-linked immunosorbent assay (ELISA), by using the kit (rat P-selectin ELISA kit; Wuhan Huamei Biotech Co., Ltd., Wuhan, Hubei Province, People's Republic of China) and by following the procedure of the literature. ${ }^{21}$ GPIIb/IIIa expression assay was based on the experiment of the ELISA by using the kit (rat GPIIb/IIIa ELISA kit; Wuhan Huamei Biotech Co., Ltd.) and by following the procedure of the literature. ${ }^{27}$ In both assays, the serum was similarly obtained from male rats treated with $5 \mu \mathrm{mol} / \mathrm{kg}$ of ICCA, $167 \mu \mathrm{mol} / \mathrm{kg}$ of aspirin (positive control), or $0.5 \% \mathrm{CMCNa}$ (negative control).

\section{Rat tail bleeding time assay}

This assay was performed by following the procedure of the literature. ${ }^{28}$ In this assay, the male Sprague Dawley rats (200-220 g) were orally treated with $0.5 \% \mathrm{CMCNa}(3 \mathrm{~mL} / \mathrm{kg}$, negative control, 12 rats), suspension of aspirin in $0.5 \%$ $\mathrm{CMCNa}(167 \mu \mathrm{mol} / \mathrm{kg}$, positive control, 12 rats $)$, or suspension of ICCA in $0.5 \% \mathrm{CMCNa}(5 \mu \mathrm{mol} / \mathrm{kg}, 12$ rats $)$.

\section{Rat venous thrombus weight assay}

This assay was performed by following the procedure of the literature. ${ }^{21}$ In this assay, male Sprague Dawley rats (250-300 g) were orally treated with $0.5 \% \mathrm{CMCNa}(3 \mathrm{~mL} / \mathrm{kg}$, negative control, 12 rats), a suspension of warfarin in $0.5 \%$ $\mathrm{CMCNa}(4.87 \mu \mathrm{mol} / \mathrm{kg}$, positive control, 12 rats), or a suspension of ICCA in $0.5 \% \mathrm{CMCNa}(5 \mu \mathrm{mol} / \mathrm{kg}, 12$ rats $)$.

Measuring serum prothrombin time (PT), thrombin time (TT), activated partial thromboplastin time (APTT), and FIB

To measure serum PT, TT, APTT, and FIB, the blood of male Sprague Dawley rats (250-300 g) orally treated with $0.5 \% \mathrm{CMCNa}(3 \mathrm{~mL} / \mathrm{kg}$, negative control, 12 rats) or a 
suspension of ICCA in $0.5 \% \mathrm{CMCNa}(5 \mu \mathrm{mol} / \mathrm{kg}, 12$ rats) was used. Serum PT, TT, APTT, and FIB were measured by semi-automatic blood coagulation instrument (Virtues Pacific Biological Polytron Technologies Inc., Tianjin, People's Republic of China).

\section{Vitamin KI (VKI) expression assay}

VK1 expression assay was based on the experiment of the ELISA by using the kit (rat VK1 ELISA kit; Shanghai Lianshuo Biological Technology Co. Ltd.). In this assay, the blood from male Sprague Dawley rats (250-300 g) orally treated with ICCA $(5 \mu \mathrm{mol} / \mathrm{kg}, 12$ rats) or $0.5 \% \mathrm{CMCNa}$ (negative control, 12 rats) was used to prepare serum by following the standard procedure. To standard well, $50 \mu \mathrm{L}$ standard solutions and $50 \mu \mathrm{L}$ streptavidin-HRP were added. To testing well having $40 \mu \mathrm{L}$ of the serum, $10 \mu \mathrm{L}$ of anti-VK1-antibody and $50 \mu \mathrm{L}$ of streptavidin-HRP were successively added. At $37^{\circ} \mathrm{C}$, the well was incubated for 60 minutes and washed five times. For coloration, $50 \mu \mathrm{L}$ chromogen solution $\mathrm{A}$ and $50 \mu \mathrm{L}$ chromogen solution B (from the kit) were added to the well, and then, it was incubated at $37^{\circ} \mathrm{C}$ in dark for 15 minutes. To stop the reaction, the well received $50 \mu \mathrm{L}$ stop solution (from the kit). The OD value was measured at $450 \mathrm{~nm}$ within 15 minutes of the addition of the stop solution. By using standard curve, serum concentration of VK1 was calculated.

\section{Coagulation factor II (FII) expression assay}

FII expression assay was based on the experiment of ELISA by using the kit (rat FII ELISA kit; Shanghai Lianshuo Biological Technology Co. Ltd.). In this assay, the blood from male Sprague Dawley rats $(250-300 \mathrm{~g})$ orally treated with ICCA ( $5 \mu \mathrm{mol} / \mathrm{kg}, 12$ rats) or $0.5 \% \mathrm{CMCNa}$ (negative control, 12 rats) was collected by using standard procedure (ie, the blood been collected into a tube containing 3.8\% sodium citrate at a ratio of $9: 1$ and centrifuged at $4{ }^{\circ} \mathrm{C}$ and $3,000 \mathrm{rpm} / \mathrm{min}$ for 10 minutes) for preparing serum; $50 \mu \mathrm{L}$ standard solutions and $50 \mu \mathrm{L}$ streptavidin-HRP were added into the standard well, and $10 \mu \mathrm{L}$ anti-FII-antibody and $50 \mu \mathrm{L}$ streptavidin-HRP were successively added into the testing well having $40 \mu \mathrm{L}$ serum from $\mathrm{CMCNa}$ - or ICCA ( $5 \mu \mathrm{mol} / \mathrm{kg}$ )-treated rats. The well was incubated at $37^{\circ} \mathrm{C}$ for 60 minutes and washed five times. For coloration, $50 \mu \mathrm{L}$ chromogen solution A and $50 \mu \mathrm{L}$ chromogen solution B of the kit were added into the well, and the well was incubated at $37^{\circ} \mathrm{C}$ in dark for 15 minutes. To stop coloration, $50 \mu \mathrm{L}$ stop solutions of the kit were added. The OD value was measured at $450 \mathrm{~nm}$ within 15 minutes of the addition of the stop solution. By using standard curve, serum concentration of FII was calculated.

\section{Coagulation factor VII (FVII) expression assay}

FVII expression assay was based on the experiment of ELISA by using kit (rat FVII ELISA kit; Shanghai Lianshuo Biological Technology Co. Ltd.). In this assay, the blood of male Sprague Dawley rats (250-300 g) orally treated with ICCA ( $5 \mu \mathrm{mol} / \mathrm{kg}, 12$ rats) or $0.5 \% \mathrm{CMCNa}$ (negative control, 12 rats) was collected by using standard procedure (ie, the blood been collected into a tube containing 3.8\% sodium citrate at a ratio of $9: 1$ and centrifuged at $4{ }^{\circ} \mathrm{C}$ and $3,000 \mathrm{rpm} / \mathrm{min}$ for 10 minutes) to prepare serum. The serum was received at 10 -fold dilution with the diluents of the kit and incubated at $37^{\circ} \mathrm{C}$ for 3 minutes to prepare blank and test serum. To control well and test well, $100 \mu \mathrm{L}$ of blank serum and $100 \mu \mathrm{L}$ of test serum were added, respectively. At $37^{\circ} \mathrm{C}$, the well was incubated for 120 minutes. After removing solvent to the well, $100 \mu \mathrm{L}$ of biotin labeling antibody of the kit was added, and the well was incubated at $37^{\circ} \mathrm{C}$ for 60 minutes. The solution in the well was discarded, and the washing solution of the kit was added to wash the well $(200 \mu \mathrm{L} \times 3)$. Then, $100 \mu \mathrm{L}$ of HRP labeling avidin of the kit was added, and the well was incubated at $37^{\circ} \mathrm{C}$ for 60 minutes and then washed five times. For coloration, $90 \mu \mathrm{L}$ substrate of the kit was added to the well, and the well was incubated at $37^{\circ} \mathrm{C}$ in dark for 30 minutes. To stop coloration, $50 \mu \mathrm{L}$ stop solution of the kit was added. The OD value of the well was measured at $450 \mathrm{~nm}$ within 15 minutes of the addition of the stop solution. By using standard curve, serum concentration of FVII was calculated.

\section{Coagulation factor IX (FIX) expression assay}

FIX expression assay was based on the experiment of ELISA and by following the procedure of the kit (rat FIX ELISA kit; Shanghai Lianshuo Biological Technology Co. Ltd.). In this assay, the blood of male Sprague Dawley rats (250-300 g) orally treated with ICCA ( $5 \mu \mathrm{mol} / \mathrm{kg}, 12$ rats) or $0.5 \% \mathrm{CMCNa}$ (negative control, 12 rats) was collected by using standard procedure (ie, the blood been collected into a tube containing $3.8 \%$ sodium citrate at a ratio of $9: 1$ and centrifuged at $4^{\circ} \mathrm{C}$ and $3,000 \mathrm{rpm} / \mathrm{min}$ for 10 minutes) to prepare serum. Then, $50 \mu \mathrm{L}$ standard solutions and $50 \mu \mathrm{L}$ streptavidin-HRP of the kit were added into standard well; $10 \mu \mathrm{L}$ anti-FIX-antibody and $50 \mu \mathrm{L}$ streptavidin-HRP were successively added into testing well having $40 \mu \mathrm{L}$ serum from the rat treated with $\mathrm{CMCNa}$ or ICCA $(5 \mu \mathrm{mol} / \mathrm{kg})$. At $37^{\circ} \mathrm{C}$, the well was incubated for 60 minutes and then washed five times. For coloration, $50 \mu \mathrm{L}$ chromogen solution A and $50 \mu \mathrm{L}$ chromogen solution $\mathrm{B}$ of the kit were added to the well, and the well was incubated at $37^{\circ} \mathrm{C}$ in dark for 15 minutes. To stop coloration, $50 \mu \mathrm{L}$ stop solution of the 
kit was added into the well. The OD value of the well was measured at $450 \mathrm{~nm}$ within 15 minutes of the addition of the stop solution. By using standard curve, serum concentration of FIX was calculated.

\section{Coagulation factor $X(F X)$ expression assay}

FX expression assay was based on the experiment of ELISA and by using the procedure of the kit (rat FX ELISA kit; Shanghai Lianshuo Biological Technology Co. Ltd.). In this assay, the blood of male Sprague Dawley rats (250-300 g) orally treated with ICCA ( $5 \mu \mathrm{mol} / \mathrm{kg}, 12$ rats) or $0.5 \% \mathrm{CMCNa}$ (negative control, 12 rats) was collected by using standard procedure (ie, the blood been collected into a tube containing $3.8 \%$ sodium citrate at a ratio of $9: 1$ and centrifuged at $4^{\circ} \mathrm{C}$ and $3,000 \mathrm{rpm} / \mathrm{min}$ for 10 minutes) to prepare serum. Then, $50 \mu \mathrm{L}$ standard solutions and $50 \mu \mathrm{L}$ streptavidin-HRP of the kit were added into standard well, and $10 \mu \mathrm{L}$ anti-FX-antibody and $50 \mu \mathrm{L}$ streptavidin-HRP were successively added into testing well having $40 \mu \mathrm{L}$ serum from CMCNa- or ICCA $(5 \mu \mathrm{mol} / \mathrm{kg})$-treated rats. The well was incubated at $37^{\circ} \mathrm{C}$ for 60 minutes and then washed five times. For coloration, $50 \mu \mathrm{L}$ chromogen solution $\mathrm{A}$ and $50 \mu \mathrm{L}$ chromogen solution $\mathrm{B}$ of the kit were added into the well, and the well was incubated $37^{\circ} \mathrm{C}$ in dark for 15 minutes. To stop coloration, $50 \mu \mathrm{L}$ stop solution (from the kit) was added into the well. The OD value of the well was measured at $450 \mathrm{~nm}$ within 15 minutes of the addition of the stop solution. By using standard curve, serum concentration of FX was calculated.

\section{Docking toward active sites of P-selectin and GPIlb/IIla} To perform docking investigation, the conformation of $\beta$-carboxylic acids and their benzyl esters was generated by following the literature. ${ }^{20,21}$ According to the literature, 10 energy-optimized conformations of each $\beta$-carboxylic acid and benzyl ester were docked into the active sites of P-selectin and GPIIb/IIIa with CDOCKER protocol and using the procedure of the literature. ${ }^{20,21}$

\section{Results and discussion ICCA was assigned as a dual inhibitor of P-selectin and GPIlb/IIla receptors}

To design a candidate capable of simultaneously downregulating P-selectin and GPIIb/IIIa receptors, the pharmacophores of 10 carbolines in the red box of Figure 1, of which the activities related to either P-selectin receptor or GPIIb/IIIa receptor were previously reported, ${ }^{19-26}$ were analyzed. The analysis of the pharmacophores marked with "oval a" led to a common pharmacophore, ie, $\beta$-carboline-3-carboxylic acid and its benzyl ester marked with "circle A." The analysis of the 1-substituents marked with "square b" led to a common 1-substituent, ie, 4-isopropylphenyl marked with "square B." Thus, the pharmacophore analysis and the 1-substituent analysis together led to the design of ICCA and its benzyl ester in the green box $\mathrm{C}$ of Figure 1 as the promising candidate capable of simultaneously downregulating P-selectin and GPIIb/IIIa receptors.

To rationally design ICCA and its benzyl ester, 10 $\beta$-carboxylic acids and their benzyl esters of the literature ${ }^{19-26}$ were docked into the active sites of both P-selectin and GPIIb/IIIa receptors by using CDOCKER protocol. Figure 1 shows that for P-selectin receptor the CDOCKER interaction energies fall within a range between -11.2 and $-33.3 \mathrm{kcal} / \mathrm{mol}$, and ICCA has the lowest CDOCKER interaction energy. Figure 1 also shows that for GPIIb/IIIa receptor the CDOCKER interaction energies fall within a range of -11.5 and $-20.2 \mathrm{kcal} / \mathrm{mol}$, and again ICCA has the lowest CDOCKER interaction energy.

To explain the possible reason of ICCA having the lowest energy, the docking features of ICCA in the active sites of P-selectin and GPIIb/IIIa are shown. Figure 1 emphasizes that ICCA, but not the others, can act on four important amino acid residues (Asn44, Glu80, Asn105, and Tyr48) of the active site of $\mathrm{P}$-selectin and on five important amino acid residues (Ser101, Phe100, Asn99, Lys98, and Ala61) of the active site of GPIIb/IIIa.

To make the present CDOCKER interaction energies of $12 \beta$-carboxylic acids and their benzyl esters been easyto-read, Table 1 was added. The data emphasize that for $\mathrm{P}$-selectin receptor the energies fall within a range of -11.2 and $-33.3 \mathrm{kcal} / \mathrm{mol}$, and ICCA has the lowest CDOCKER interaction energy. The data also emphasize that for GPIIb/IIIa receptor the CDOCKER interaction energies fall within a range of -11.5 and $-20.2 \mathrm{kcal} / \mathrm{mol}$, and again ICCA has the lowest CDOCKER interaction energy.

\section{Route suitable for the preparation of ICCA}

To process the investigations, ICCA was synthesized by following the route depicted in Scheme 1. Briefly, the Pictet-Spengler condensation of $L$-Trp-OBzl and cuminic aldehyde provided (1R, 3S)-1-(4-isopropyl-phenyl)-2,3,4,9tetrahydro- $\beta$-carboline-3-carboxylic acid benzyl esters (1) in $60 \%$ yield. In the presence of $\mathrm{SeO}_{2}$, it was converted to ICCA benzyl ester (2) in $89 \%$ yield. At $0^{\circ} \mathrm{C}$ and in aqueous $\mathrm{NaOH}(2 \mathrm{M})$, the hydrolysis of (2) was performed, and ICCA was provided in 90\% yield and 99.6\% HPLC purity. 


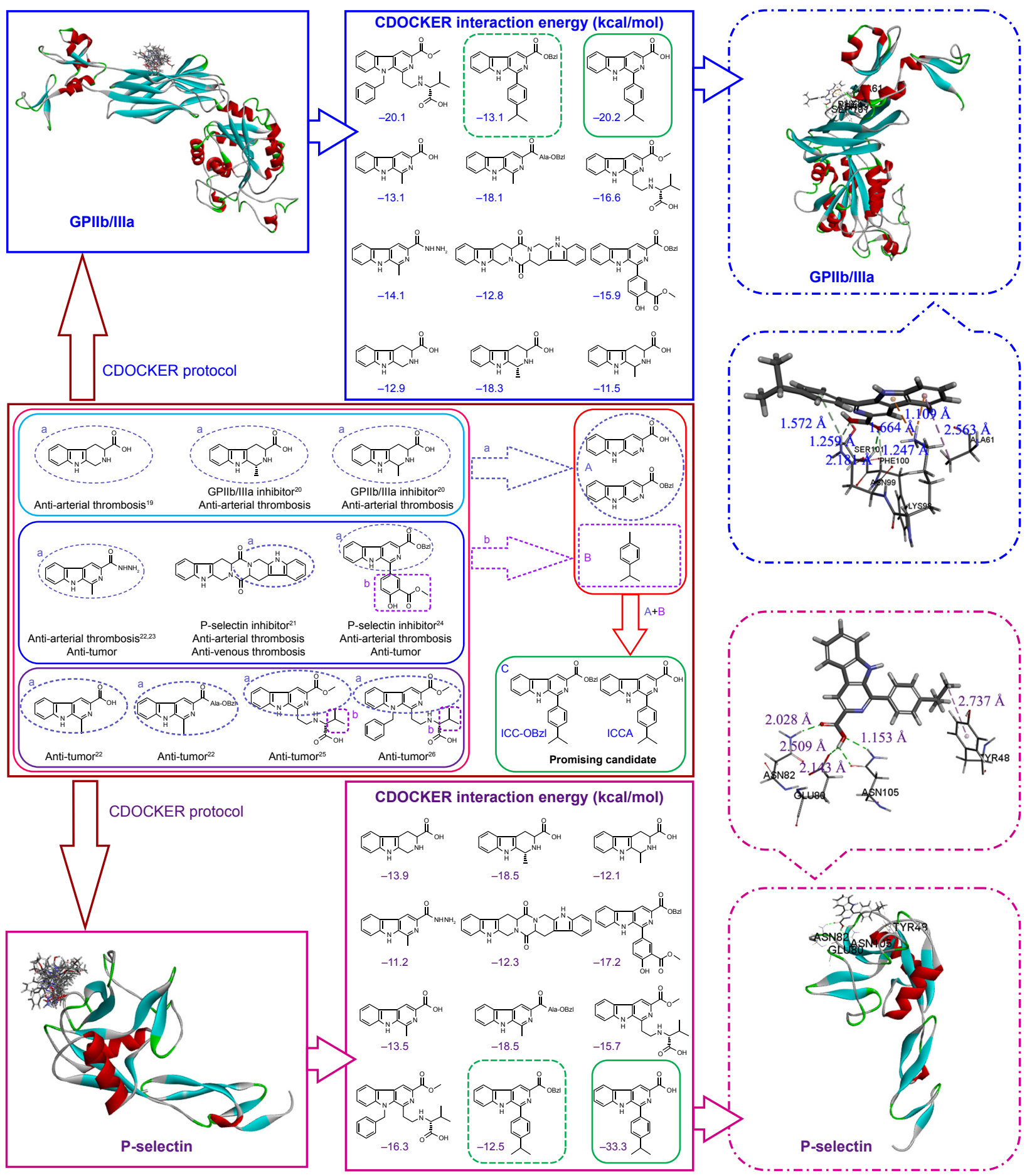

Figure I Structural analysis and docking investigation led to ICCA been assigned as an inhibitor of both P-selectin and GPIIb/Illa receptors.

Abbreviations: GPIIb/Illa, platelet membrane glycoprotein Ilb/llla; ICCA, I-(4-isopropylphenyl)- $\beta$-carboline-3-carboxylic acid.

The proper reaction condition, the desirable yields, and the high purity emphasize that the synthetic route is suitable for the preparation of ICCA.

\section{ICCA effectively inhibits arterial thrombosis in vivo}

To evidence the rationality of the design, the arterial thrombotic assays of ICCA were performed on both mouse and rat models. ${ }^{19,21}$ Figure $2 \mathrm{~A}$ shows that the arterial thrombus weights of the mice orally treated with $5 \mu \mathrm{mol} / \mathrm{kg}$ of ICCA are significantly lower than those of the mice orally treated with $\mathrm{CMCNa}$ and $24 \mu \mathrm{mol} / \mathrm{kg}$ of aspirin. This means that $5 \mu \mathrm{mol} / \mathrm{kg}$ oral ICCA effectively inhibits the mice to form arterial thrombus. The dose of aspirin is 4.8 folds of ICCA; this also means that the antithrombosis activity of ICCA is 4.8 folds higher than that of aspirin. 
Table I CDOCKER interaction energies and activities of $\beta$-carboxylic acids and benzyl esters

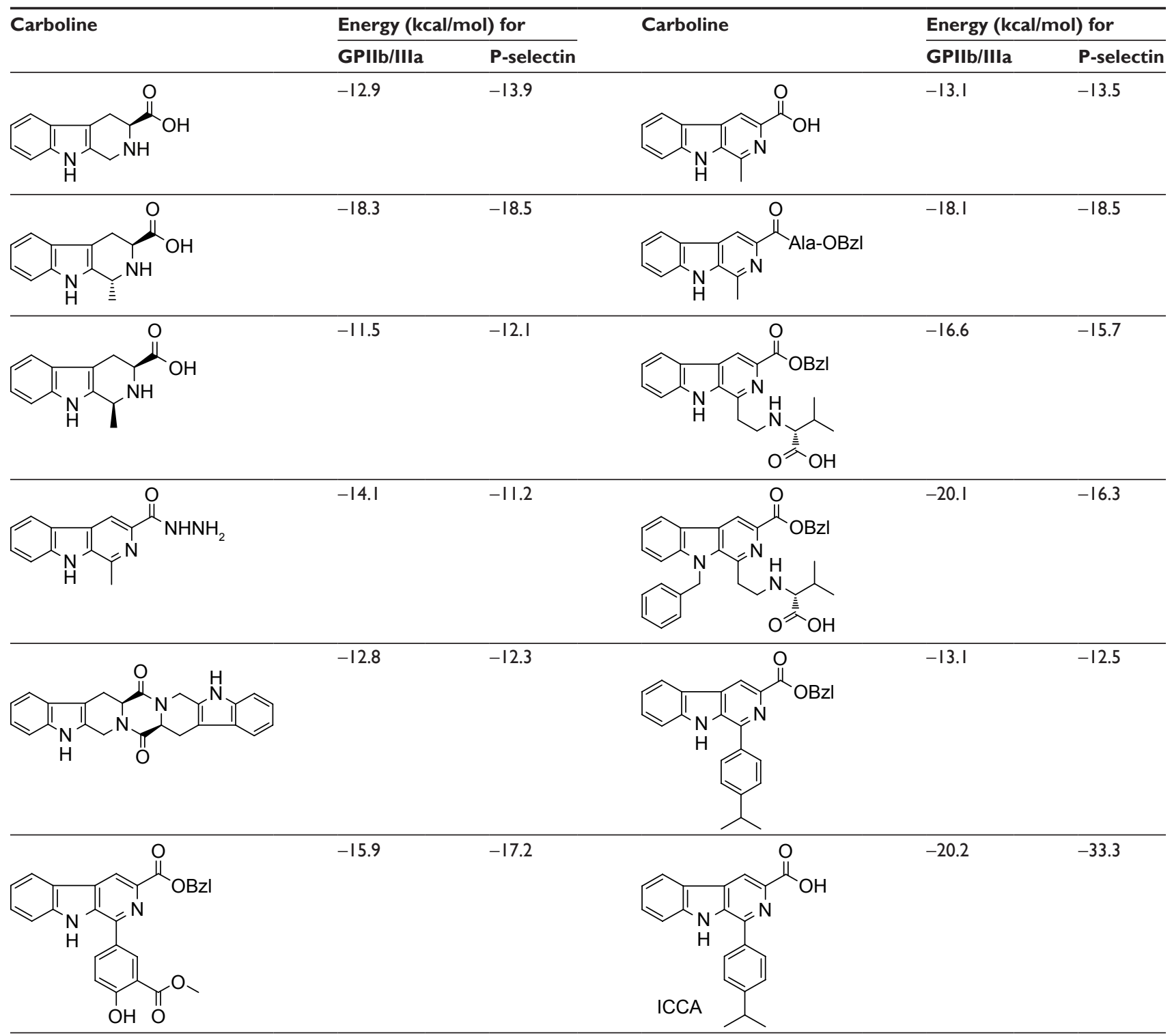

Abbreviation: GP, glycoprotein.

Figure 2B shows that the arterial thrombus weights of the rats orally treated with $5 \mu \mathrm{mol} / \mathrm{kg}$ of ICCA are significantly lower than those of the rats orally treated with $\mathrm{CMCNa}$ and $16.7 \mu \mathrm{mol} / \mathrm{kg}$ of aspirin. This means that $5 \mu \mathrm{mol} / \mathrm{kg}$ oral
ICCA effectively inhibits the rats to form arterial thrombus. The dose of aspirin is 3.3 folds of ICCA; this also means that the antithrombosis activity of ICCA is 3.3 folds higher than that of aspirin.

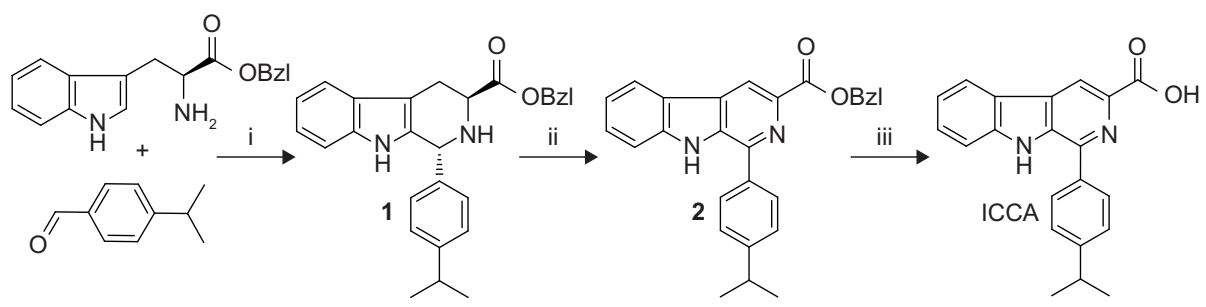

Scheme I Synthetic route of ICCA: (i) TFA, $\mathrm{CH}_{2} \mathrm{Cl}_{2}$; (ii) $\mathrm{SeO}_{2}$, I,4-dioxane and 70 ${ }^{\circ} \mathrm{C}$; (iii) aqueous $\mathrm{NaOH}$ (2M), I,4-dioxane and $0{ }^{\circ} \mathrm{C}$.

Abbreviations: $\mathrm{CH}_{2} \mathrm{Cl}_{2}$, dichloromethane; ICCA, I-(4-isopropylphenyl)- $\beta$-carboline-3-carboxylic acid; SeO , selenium dioxide; TFA, trifluoroacetic acid; $\mathrm{NaOH}$, sodium hydroxide. 
A

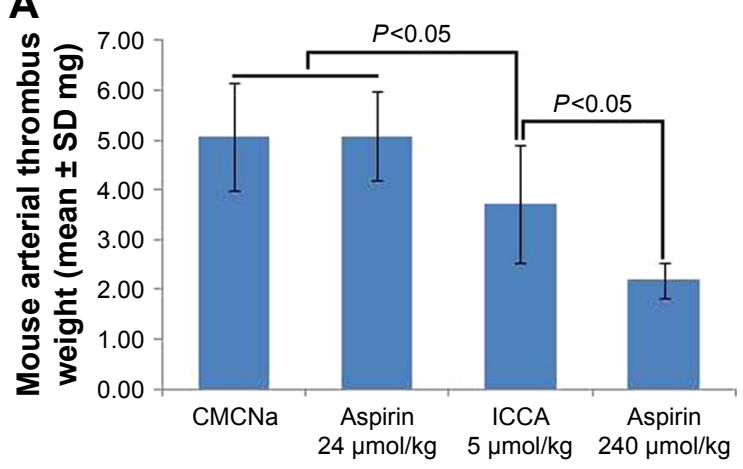

B

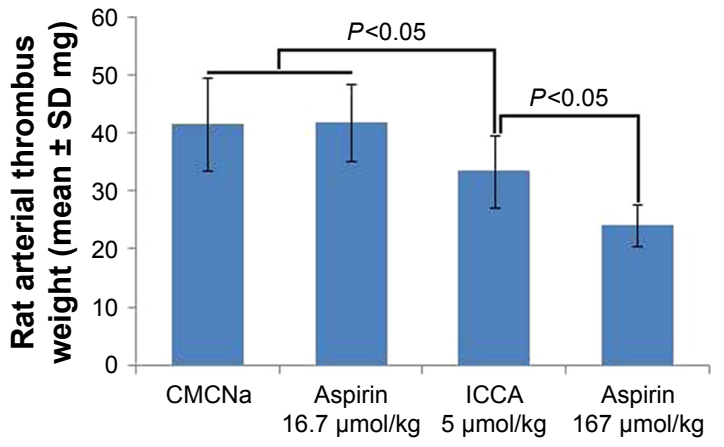

C

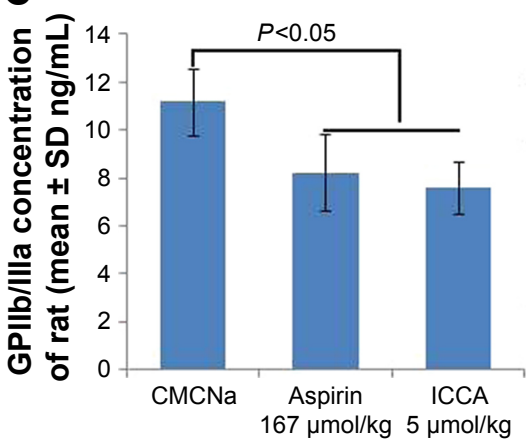

D

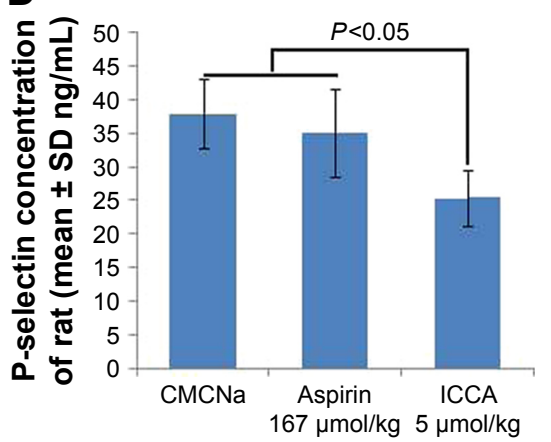

$\mathbf{E}$

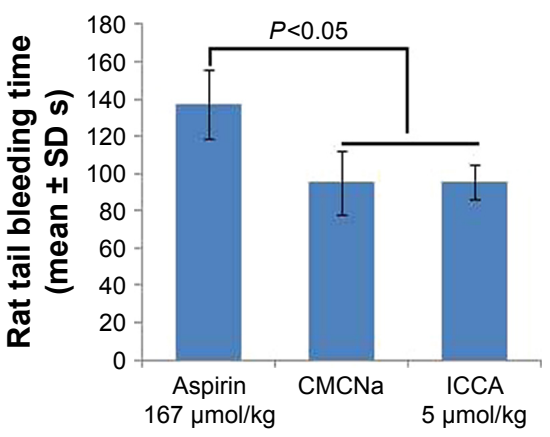

Figure 2 Efficacy of ICCA in the arterial thrombotic assays, $n=12$ : (A) At $5 \mu \mathrm{mol} / \mathrm{kg}$ of oral dose, ICCA effectively inhibits the mice to form arterial thrombus; (B) at $5 \mu \mathrm{mol} / \mathrm{kg}$ of oral dose, ICCA effectively inhibits the rats to form arterial thrombus; (C) $5 \mu \mathrm{mol} / \mathrm{kg}$ ICCA decreases GPIIb/llla in arterial serum of the treated thrombosis rats; (D) $5 \mu \mathrm{mol} / \mathrm{kg}$ ICCA decreases P-selectin in arterial serum of the treated thrombosis rats; (E) $5 \mu \mathrm{mol} / \mathrm{kg}$ ICCA does not prolong the tail bleeding time of the treated thrombosis rats.

Abbreviations: CMCNa, carboxymethyl cellulose sodium; GPIlb/llla, platelet membrane glycoprotein Ilb/Illa; ICCA, I-(4-isopropylphenyl)- $\beta$-carboline-3-carboxylic acid.

\section{ICCA downregulates GPIlb/Illa and $P$-selectin expression in vivo}

To evidence the rationality of the design, the in vivo expression of GPIIb/IIIa and P-selectin was examined by following the reported methods. ${ }^{21,27}$ Serum GPIIb/IIIa and P-selectin of the rats treated with $5 \mu \mathrm{mol} / \mathrm{kg}$ ICCA are significantly lower than those of the rats treated with $\mathrm{CMCNa}$ and are equal to those of the rats treated with $167 \mu \mathrm{mol} / \mathrm{kg}$ aspirin, respectively (Figure 2C and D). Thus, by downregulating GPIIb/IIIa and P-selectin expression, ICCA effectively inhibits arterial thrombus of rats. Besides, the efficacy of ICCA downregulating the expression of GPIIb/IIIa and P-selectin is 33 folds higher than that of aspirin.

\section{ICCA has no bleeding risk}

To estimate whether ICCA has a bleeding risk, the tail bleeding time assay was performed by following the reported method. ${ }^{28}$ It was found that $5 \mu \mathrm{mol} / \mathrm{kg}$ oral ICCA, but not $167 \mu \mathrm{mol} / \mathrm{kg}$ oral aspirin, did not prolong tail bleeding time of the treated rats (Figure 2E). Therefore, ICCA, but not aspirin, has no bleeding risk.

\section{ICCA effectively inhibits venous thrombosis in vivo}

To evidence the rationality of the design, the venous thrombotic assay of ICCA was performed on rat model. ${ }^{21}$ It was found that the venous thrombus weight of the rats orally treated with $5 \mu \mathrm{mol} / \mathrm{kg}$ ICCA was significantly lower than that of the rats orally treated with $\mathrm{CMCNa}$ and equal to that of the rats orally treated with $4.87 \mu \mathrm{mol} / \mathrm{kg}$ warfarin (Figure $3 \mathrm{~A}$ ). This means that $5 \mu \mathrm{mol} / \mathrm{kg}$ of oral ICCA effectively inhibits venous thrombosis in vivo. Besides, the efficacy of $5 \mu \mathrm{mol} / \mathrm{kg}$ of ICCA is equal to that of $4.87 \mu \mathrm{mol} / \mathrm{kg}$ of warfarin.

\section{ICCA is not warfarin- and heparin-like anticoagulant}

To ensure ICCA been downregulator of GPIIb/IIIa and $\mathrm{P}$-selectin receptors, but not a warfarin- and heparin-like anticoagulant, the PT, TT, APTT, FIB, VK1, FII, FVII, FIX, and $\mathrm{FX}$ of venous thrombosis rats treated with $5 \mu \mathrm{mol} / \mathrm{kg}$ ICCA were measured by using the reported methods. ${ }^{29}$ Figure $3 \mathrm{~B}$ and $\mathrm{C}$ indicates that $5 \mu \mathrm{mol} / \mathrm{kg}$ of ICCA does not alter serum levels of PT, TT, APTT, FIB, VK1, FII, FVII, FIX, and FX 
A

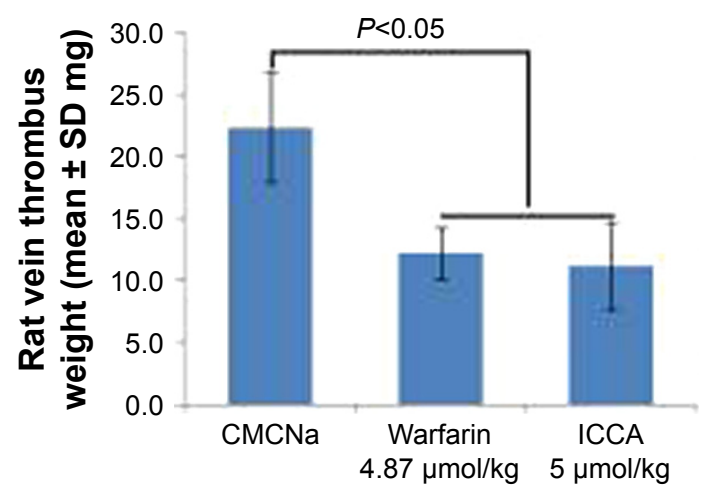

B

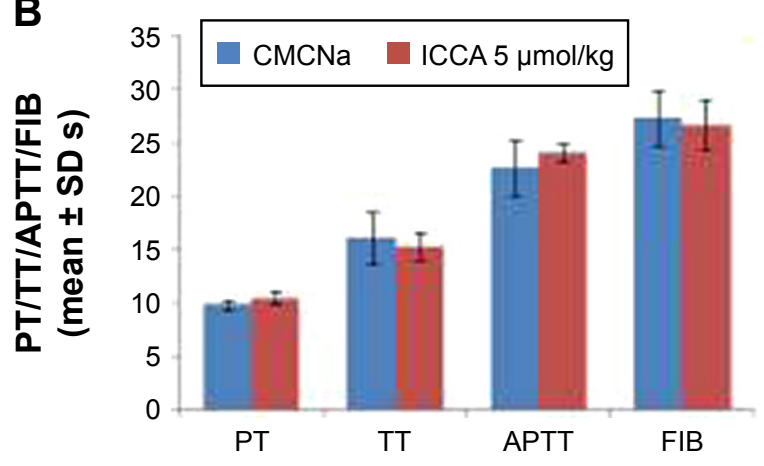

C

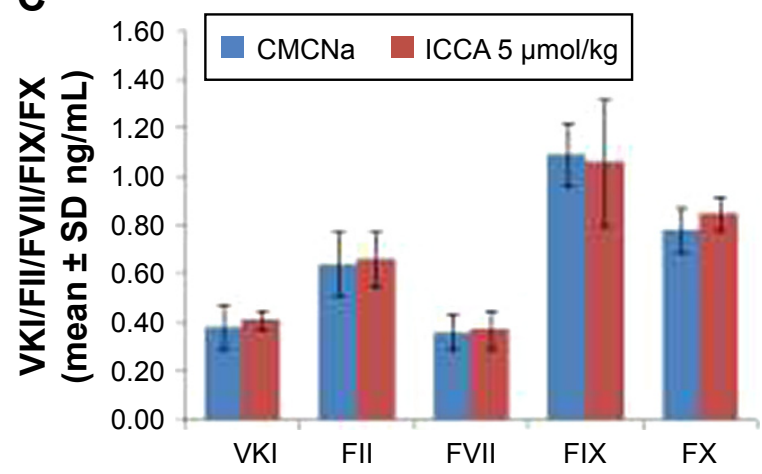

Figure 3 Efficacy of ICCA in venous thrombotic assay: (A) venous thrombus weight of rats orally treated with $5 \mu \mathrm{mol} / \mathrm{kg}$ ICCA, $\mathrm{n}=12$; (B) PT, TT, APTT, and FIB of the venous thrombosis rats treated with $5 \mu \mathrm{mol} / \mathrm{kg}$ ICCA, $\mathrm{n}=\mathrm{I} 2$; (C) serum VKI, FII, FVII, FIX, and FX of venous thrombosis rats treated with $5 \mu \mathrm{mol} / \mathrm{kg}$ ICCA; $\mathrm{n}=12$.

Abbreviations: APTT, activated partial thromboplastin time; $\mathrm{CMCNa}$, carboxymethyl cellulose sodium; FII, coagulation factor II; FVII, coagulation factor VII; FIX, coagulation factor IX; FX, coagulation factor X; FIB, plasma fibrinogen; ICCA, I-(4-isopropylphenyl)- $\beta$-carboline-3-carboxylic acid; PT, prothrombin time; $\mathrm{TT}$, thrombin time; VKI, vitamin KI.

of the treated rats, ie, the levels fall within the normal range. ICCA is a downregulator of GPIIb/IIIa and P-selectin receptors, but not warfarin- and heparin-like anticoagulants.

\section{ICCA has no in vitro cytotoxicity}

To examine the cytotoxicity of ICCA, the proliferation assays were performed on A549, 95D, K562, and S180 cell models by using MTT method. ${ }^{22}$ Figure 4A shows that the viabilities of $100 \mu \mathrm{M}$ of ICCA-treated A549, 95D, K562, and $\mathrm{S} 180$ cells are $<50 \%$. The $\mathrm{IC}_{50}$ values of ICCA against the proliferation of the cancer cells are $>100 \mu \mathrm{M}$, ie, ICCA has no cytotoxicity for cancer cells. Therefore, ICCA should not be considered a cytotoxic agent.

\section{ICCA effectively slows tumor growth in vivo}

To evidence the rationality of the design, the tumor growth assay of ICCA was performed on S180 mouse model. ${ }^{25}$ Figure 4B shows that the tumor weight of S180 mice orally treated with $5 \mu \mathrm{mol} / \mathrm{kg} /$ day of ICCA for 9 consecutive days is significantly lower than that of S180 mice orally treated with $\mathrm{CMCNa}$. Considering that the $\mathrm{IC}_{50}$ of ICCA inhibiting S180 cell proliferation is $>100 \mu \mathrm{M}$ and ICCA is not a cytotoxic agent (Figure 4A), the in vivo efficacy of ICCA slowing tumor growth could be correlated with the in vivo downregulating GPIIb/IIIa and P-selectin expression.

To further evidence the correlation of ICCA slowing down tumor growth with the downregulation of GPIIb/ IIIa and P-selectin expression, but not the inhibition of cancer cell proliferation, the existence of ICCA in the tumor tissue of S180 mice orally treated with CMCNa and $5 \mu \mathrm{mol} / \mathrm{kg}$ /day ICCA for 9 consecutive days was examined by ESI(-)-FT-MS qualitatively. However, ESI(-)-FT-MS spectra gave no peak related to ICCA. This ensures that the in vivo antitumor action of ICCA is independent on the direct cytotoxic activity and supports the impact of downregulating GPIIb/IIIa and P-selectin expression on tumor growth.

\section{ICCA has no liver and renal toxicity}

The serum ALT, AST, Cr, and BUN are commonly used to estimate the toxicity of the drug to kidney and liver. ${ }^{30}$ In this regard, the serum ALT, AST, Cr, and BUN of the S180 mice treated with $5 \mu \mathrm{mol} / \mathrm{kg} / \mathrm{day}$ of ICCA for 9 consecutive days were measured by using the corresponding kits. Figure $4 \mathrm{C}-\mathrm{F}$ shows that after receiving ICCA, the serum ALT, AST, Cr, and BUN of the S180 mice are equal to those of the healthy mice. Therefore, the therapy of $5 \mu \mathrm{mol} / \mathrm{kg}$ of ICCA does not injure the kidney and the liver.

\section{Comparing the activities of 9 carbolines}

To get insight into the dependence of bioactivity on the structure of $\beta$-carboline, the antiproliferation, antitumor, and antithrombosis activities of ICCA and carbolines were compared. 
A
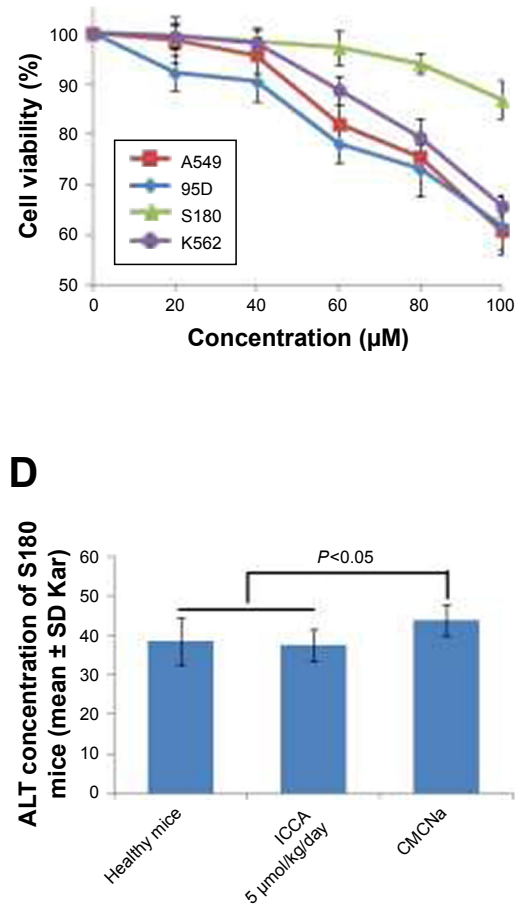

B

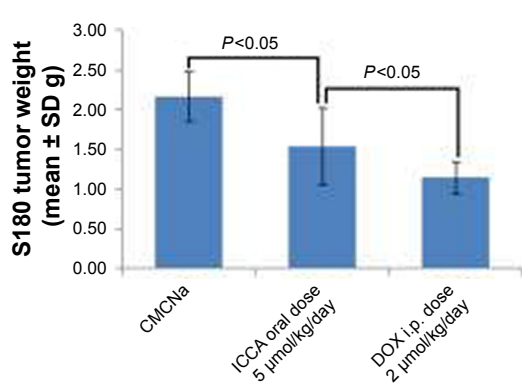

E

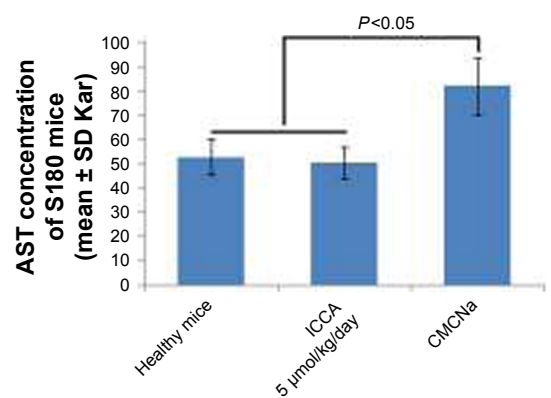

C
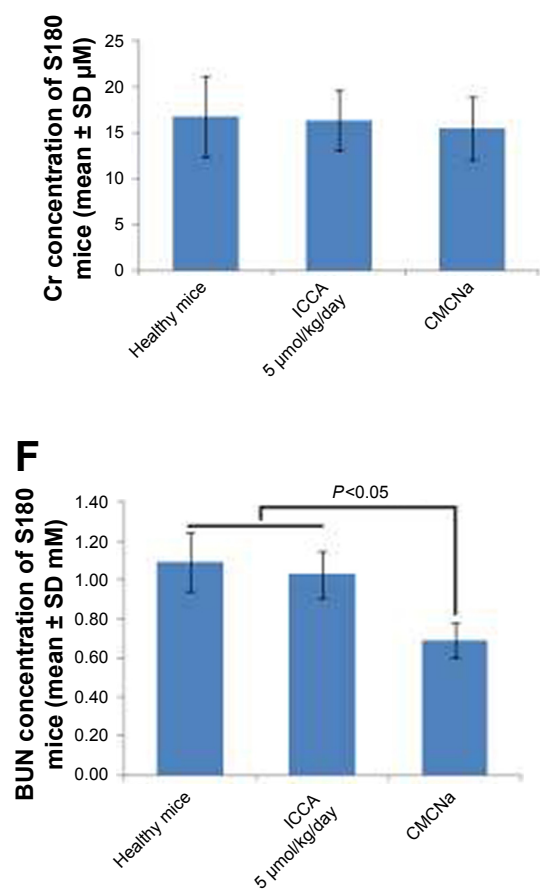

Figure 4 Antiproliferation activity in vitro, antitumor activity in vivo, and toxicity of ICCA: (A) cell viabilities of ICCA-treated A549, 95D, K562, and SI80 cells, $n=6$; (B) tumor weight of SI80 mice orally treated with $5 \mu \mathrm{mol} / \mathrm{kg} /$ day ICCA for 9 consecutive days, $\mathrm{n}=12$; (C) $\mathrm{Cr}$ of SI80 mice orally receiving $5 \mu \mathrm{mol} / \mathrm{kg} / \mathrm{day}$ ICCA for 9 consecutive days, $\mathrm{n}=6$; (D) ALT of SI 80 mice orally receiving $5 \mu \mathrm{mol} / \mathrm{kg} /$ day ICCA for 9 consecutive days, $\mathrm{n}=6$; (E) AST of SI $80 \mathrm{mice}$ orally receiving $5 \mu \mathrm{mol} / \mathrm{kg} /$ day ICCA for 9 consecutive days, $\mathrm{n}=6$; (F) BUN of SI 80 mice orally receiving $5 \mu \mathrm{mol} / \mathrm{kg} /$ day ICCA for 9 consecutive days, $\mathrm{n}=6$.

Abbreviations: 95D, nonsmall cell lung cancer cell line; ALT, alanine transaminase; AST, aspartate transaminase; BUN, blood urea nitrogen; CMCNa, carboxymethyl cellulose sodium; Cr, creatinine; DOX, doxorubicin; ICCA, I-(4-isopropylphenyl)- $\beta$-carboline-3-carboxylic acid; K562, human myeloid leukemia; SI80, ascites tumor cells; Kar, Karmen.

Table 2 shows that the $\mathrm{IC}_{50}$ values of ICCA inhibiting the proliferation of HeLa, MCF-7, HepG2, and K562 cells are $>100 \mu \mathrm{M}$. This is in consistent with the finding that ICCA is a downregulator of P-selectin and GPIIb/IIIa receptors, but not a cytotoxic agent. Similar $\mathrm{IC}_{50}$ values are also given by 1-methyl- $\beta$-caboline-3-carboxylic acid, but it was reported as an intercalator.

Table 3 indicates that the tumor weight of $5 \mu \mathrm{mol} / \mathrm{kg} /$ day of ICCA-treated S180 mice is significantly higher than that of $0.1 \mu \mathrm{mol} / \mathrm{kg} / \mathrm{day}$ of

Table $2 \mathrm{IC}_{50}$ of ICCA and four carbolines inhibiting cancer cell proliferation

\begin{tabular}{|c|c|c|c|c|c|}
\hline \multirow[t]{2}{*}{ Carboline } & \multicolumn{4}{|c|}{$I C_{50}$ inhibiting the proliferation of the following cells } & \multirow[t]{2}{*}{ References } \\
\hline & HeLa & MCF-7 & HepG2 & K562 & \\
\hline & $>100 \mu \mathrm{M}$ & $>100 \mu \mathrm{M}$ & $>100 \mu \mathrm{M}$ & $>100 \mu \mathrm{M}$ & - \\
\hline & $>100 \mu \mathrm{M}$ & $>100 \mu \mathrm{M}$ & $>100 \mu \mathrm{M}$ & Not available & 22 \\
\hline & $19 \mu \mathrm{M}$ & $30 \mu \mathrm{M}$ & $49 \mu \mathrm{M}$ & Not available & 22 \\
\hline
\end{tabular}


Table 2 (Continued)

\begin{tabular}{llllll}
\hline Carboline & \multicolumn{3}{l}{ IC References } \\
\cline { 2 - 5 } & HeLa & MCF-7 & HepG2 & K562 \\
\hline
\end{tabular}

Abbreviation: ICCA, I-(4-isopropyl-phenyl)- $\beta$-carboline-3-carboxylic acid.

Table 3 Tumor weights of ICCA and three carbolines-treated S180 mice

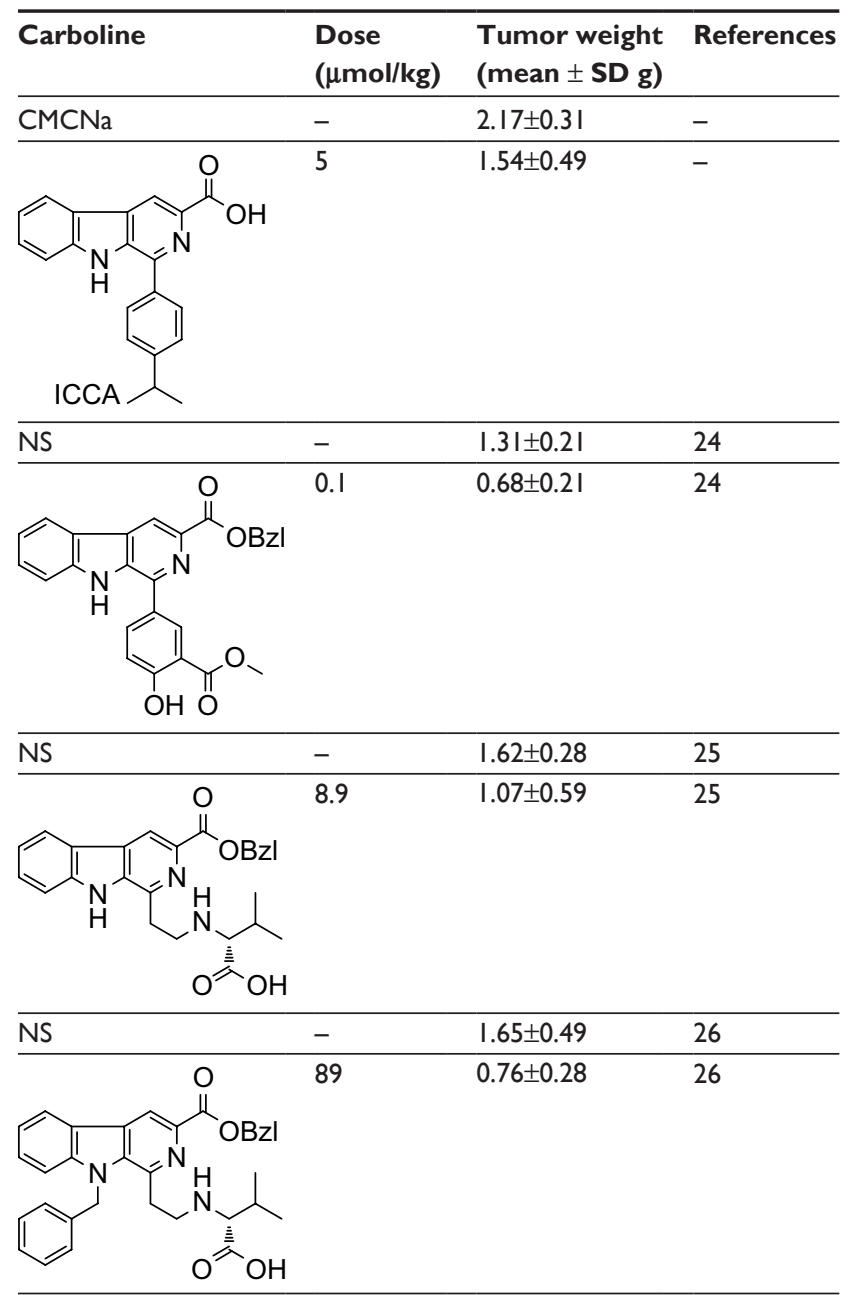

Abbreviations: CMCNa, carboxymethyl cellulose sodium; ICCA, I-(4-isopropylphenyl)- $\beta$-carboline-3-carboxylic acid; NS, normal saline. 1-(3-methoxycarbonyl-4-hydro-xylphenyl)- $\beta$-caboline-3carboxylic acid benzyl ester, an intercalator. Again, this is consistent with the finding that ICCA is a downregulator of P-selectin and GPIIb/IIIa receptors, but not a cytotoxic agent. On the other hand, however, the tumor weights of $5 \mu \mathrm{mol} / \mathrm{kg} /$ day of ICCA-treated S180 mice are significantly lower than those of other intercalators, suggesting the advantage of the downregulator of P-selectin and GPIIb/ IIIa receptors.

Table 4 shows that only $5 \mu \mathrm{mol} / \mathrm{kg}$ of ICCA can simultaneously inhibit the formation of arterial and venous thrombus. Due to deep venous embolism and arterial embolism been responsible for elevated mortality worldwide, the therapy efficacies support the clinical importance of the design and the development of ICCA as the downregulator of P-selectin and GPIIb/IIIa receptors.

\section{Conclusion}

The analysis of structural characteristic and CDOCKER interaction energy of antiarterial thrombotic carboline, antivenous thrombotic carboline, and antitumor carboline leads to the successful design of ICCA. The synthetic route is able to provide ICCA in high yield and high purity. The in vivo bioassay ensures that oral ICCA effectively inhibits arterial thrombosis, venous thrombosis, and tumor growth, but does not injure the kidney and the liver. All data emphasized that ICCA is a promising candidate of the downregulator of GPIIb/IIIa and P-selectin receptors and thereby is worthy of considering for development. 
Table 4 Thrombus weights ICCA and four carbolines-treated thrombosis rats

\begin{tabular}{|c|c|c|c|c|}
\hline \multirow[t]{2}{*}{ Compound } & \multirow{2}{*}{$\begin{array}{l}\text { Dose } \\
(\mu \mathrm{mol} / \mathrm{kg})\end{array}$} & \multicolumn{2}{|c|}{ Thrombus weight (mean \pm SD mg) } & \multirow[t]{2}{*}{ References } \\
\hline & & Arterial & Venous & \\
\hline $\mathrm{CMCNa}$ & - & $41.64 \pm 8.00$ & $22.4 \pm 4.4$ & - \\
\hline & 5 & $33.49 \pm 6.25$ & $11.2 \pm 3.5$ & - \\
\hline NS & - & $38.67 \pm 3.26$ & Not available & 19 \\
\hline & 5 & $29.69 \pm 3.22$ & Not available & 19 \\
\hline NS & - & $37.86 \pm 2.94$ & Not available & 20 \\
\hline & 1 & $27.69 \pm 3.55$ & Not available & 20 \\
\hline & 1 & $31.37 \pm 3.79$ & Not available & 20 \\
\hline NS & - & $31.87 \pm 1.71$ & Not available & 23 \\
\hline & 10 & $26.66 \pm 1.19$ & Not available & 23 \\
\hline
\end{tabular}

Abbreviations: CMCNa, carboxymethyl cellulose sodium; ICCA, I-(4-isopropyl-phenyl)- $\beta$-carboline-3-carboxylic acid; NS, normal saline.

\section{Acknowledgment}

The authors thank the Special Project of China (2017ZX09201008), NSFC (81673303 and 81703332), KZ201610025029, BNSF (7172028), 2016000020124G096, and 2017000020124G264 for financial support.

\section{Disclosure}

The authors report no conflicts of interest in this work.

\section{References}

1. Moretti A, Ferrari F, Villa RF. Pharmacological therapy of acute ischaemic stroke: achievements and problems. Pharmacol Ther. 2015; 153:79-89.

2. Granger DN, Kvietys PR. Reperfusion therapy - what's with the obstructed, leaky and broken capillaries. Pathophysiology. 2017;24: 213-228.

3. Bonechi C, Lamponi S, Donati A, et al. Effect of resveratrol on platelet aggregation by fibrinogen protection. Biophys Chem. 2017;222:41-48.
4. van der Spuy WJ, Augustine TN. Ultrastructural investigation of the time-dependent relationship between breast cancer cells and thrombosis induction. Micron. 2016;90:59-63.

5. Castaman G. Risk of thrombosis in cancer and the role of supportive care (trans-fusion, catheters, and growth factors). Thromb Res. 2016;140: S89-S92.

6. Nasti TH, Bullard DC, Yusuf N. P-selectin enhances growth and metastasis of mouse mammary tumors by promoting regulatory $\mathrm{T}$ cell infiltration into the tumors. Life Sci. 2015;131:11-18.

7. Amano H, Ito Y, Ogawa F, et al. Angiotensin II type $1 \mathrm{~A}$ receptor signaling facilitates tumor metastasis formation through P-selectin-mediated interaction of tumor cells with platelets and endothelial cells. Am J Pathol. 2013;182:553-564.

8. Pusch G, Debrabant B, Molnar T, et al. Early dynamics of P-selectin and interleukin 6 predicts outcomes in ischemic stroke. J Stroke Cerebrovasc Dis. 2015;24:1938-1947.

9. Wassel CL, Berardi C, Pankow JS, et al. Soluble P-selectin predicts lower extremity peripheral artery disease incidence and change in the ankle brachial index: the Multi-Ethnic Study of Atherosclerosis (MESA). Atherosclerosis. 2015;239:405-411.

10. Alfonso F, Angiolillo DJ. Targeting P-selectin during coronary interventions: the elusive link between inflammation and platelets to prevent myocardial damage. J Am Coll Cardiol. 2013;61:2056-2059. 
11. Juenet M, Aid-Launais R, Li B, et al. Thrombolytic therapy based on fucoidan-functionalized polymer nanoparticles targeting p-selectin. Biomaterials. 2018;156:204-216.

12. Khan R, Spagnoli V, Tardif JC, L'Allier PL. Novel anti-inflammatory therapies for the treatment of atherosclerosis. Atherosclerosis. 2015; 240:497-509.

13. Xu W, Zhao M, Wang Y, et al. Design, synthesis, and in vivo evaluations of benzyl $\mathrm{N}^{\omega}$-nitro- $\mathrm{N}^{\alpha}$-(9H-pyrido[3,4-b]indole-3-carbonyl)L-argininate as an apoptosis inducer capable of decreasing the serum concentration of P-selectin. Med Chem Commun. 2016;7:1730-1737.

14. Chen H, Wang W, Zhang X, et al. Discovery of DEBIC to correlate P-selectin inhibition and DNA intercalation in cancer therapy and complicated thrombosis. Oncotarget. 2017.

15. Kanic V, Vollrath M, Penko M, Markota A, Kompara G, Kanic Z. GPIIb-IIIa receptor inhibitors in acute coronary syndrome patients presenting with cardiogenic shock and/or after cardiopulmonary resuscitation. Heart Lung Circ. 2018;27:73-78.

16. Emani S, Kaza AK, Almodovar M, Thiagarajan R, Emani SM. Intravenous GPIIb/IIIa inhibitor for secondary prevention of shunt thrombosis in a pediatric patient. Ann Thorac Surg. 2015;99:e151-e153.

17. Yan M, Jurasz P. The role of platelets in the tumor microenvironment: from solid tumors to leukemia. Biochim Biophys Acta. 2016;1863: $392-400$.

18. Goubran HA, Burnouf T, Radosevic M, El-Ekiaby M. The plateletcancer loop. Eur J Inter Med. 2013;24:393-400.

19. Zhao M, Bi L, Bi W, et al. Synthesis of new class dipeptide analogues with improved permeability and antithrombotic activity. Bioorg Med Chem. 2006;14:4761-4774.

20. Wang X, Wang Y, Wu J, et al. Docking based design of diastereoisomeric MTCA as GPIIb/IIIa receptor inhibitor. Bioorg Med Chem Lett. 2017;27:5114-5118.

21. Zhu H, Wang Y, Song C, et al. Docking of THPDTPI: to explore P-selectin as a common target of anti-tumor, anti-thrombotic and antiinflammatory agent. Oncotarget. 2017;9:268-281.
22. Zhao M, Bi L, Wang W, et al. Synthesis and cytotoxic activities of $\beta$-carboline amino acid ester conjugates. Bioorg Med Chem. 2006;14: $6998-7010$

23. Li C, Zhang X, Zhao M, et al. A class of novel N-(1-methyl- $\beta$ carboline-3-carbonyl)- $\mathrm{N}^{\prime}$-(aminoacid-acyl)-hydrazines: aromatization leaded design, synthesis, in vitro anti-platelet aggregation/in vivo antithrombotic evaluation and 3D QSAR analysis. Eur J Med Chem. 2011; 46:5598-5608.

24. Li S, Wang Y, Zhao M, Wu J, Peng S. BPIC: a novel anti-tumor lead capable of inhibiting inflammation and scavenging free radicals. Bioorg Med Chem Lett. 2015;25:1146-1150.

25. Wu J, Li C, Zhao M, Wang W, Wang Y, Peng S. A class of novel carboline intercalators: their synthesis, in vitro anti-proliferation, in vivo anti-tumor action, and 3D QSAR analysis. Bioorg Med Chem. 2010; 18(17):6220-6229.

26. Wu J, Zhao M, Qian K, Lee KH, Morris-Natschke S, Peng S. Novel N-(3carboxyl-9-benzyl-beta-carboline-1-yl)ethylamino acids: synthesis, anti-tumor evaluation, intercalating determination, 3D QSAR analysis and docking investigation. Eur J Med Chem. 2009;44:4153-4161.

27. Jin S, Wang Y, Zhu H, et al. Nanosized aspirin-Arg-Gly-Asp-Val: delivery of aspirin to thrombus by the target carrier Arg-Gly-Asp-Val tetrapeptide. ACS Nano. 2013;7:7664-7673.

28. Gadi D, Bnouham M, Aziz M, et al. Parsley extract inhibits in vitro and ex vivo platelet aggregation and prolongs bleeding time in rats. J Ethnopharmacol. 2009;125:170-174.

29. Kluft C, van Leuven CJ. Consequences for the APTT due to direct action of factor XIa on factor X, resulting in bypassing factors VIII-IX. Thromb Res. 2015;135:198-204.

30. $\mathrm{Hu} \mathrm{X}$, Zhao M, Wang Y, et al. Tetrahydro- $\beta$-carboline-3-carboxylthymopentin: a nano-conjugate for releasing pharmacophores to treat tumor and complications. J Mater Chem B. 2016;4:1384-1397.
Drug Design, Development and Therapy

\section{Publish your work in this journal}

Drug Design, Development and Therapy is an international, peerreviewed open-access journal that spans the spectrum of drug design and development through to clinical applications. Clinical outcomes, patient safety, and programs for the development and effective, safe, and sustained use of medicines are the features of the journal, which

\section{Dovepress}

has also been accepted for indexing on PubMed Central. The manuscript management system is completely online and includes a very quick and fair peer-review system, which is all easy to use. Visit http://www.dovepress.com/testimonials.php to read real quotes from published authors. 